\title{
Lead Isotope Determinations from Sulfide Mineral Occurrences-Russian Far East
}

Data Series 743 



\section{Lead Isotope Determinations from Sulfide Mineral Occurrences-Russian Far East}

By Stanley E. Church, Nikolai A. Goryachev, and Vladimir I. Shpikerman

Data Series 743

U.S. Department of the Interior

U.S. Geological Survey 


\title{
U.S. Department of the Interior \\ KEN SALAZAR, Secretary
}

\author{
U.S. Geological Survey \\ Suzette M. Kimball, Acting Director
}

U.S. Geological Survey, Reston, Virginia: 2013

For more information on the USGS - the Federal source for science about the Earth, its natural and living resources, natural hazards, and the environment, visit http://www.usgs.gov or call 1-888-ASK-USGS.

For an overview of USGS information products, including maps, imagery, and publications, visit http://www.usgs.gov/pubprod

To order this and other USGS information products, visit http://store.usgs.gov

Any use of trade, firm, or product names is for descriptive purposes only and does not imply endorsement by the U.S. Government.

Although this information product, for the most part, is in the public domain, it also may contain copyrighted materials as noted in the text. Permission to reproduce copyrighted items must be secured from the copyright owner.

Suggested citation:

Church, S.E., Goryachev, N.A., and Shpikerman, V.I., 2013, Lead isotope determinations from sulfide mineral occurrences-Russian Far East: U. S. Geological Survey Data Series 743, 3 p. 


\section{Contents}

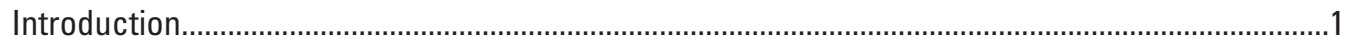

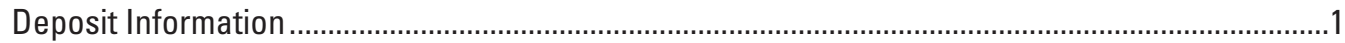

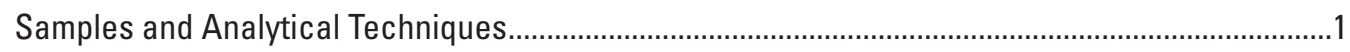

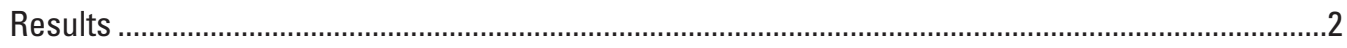

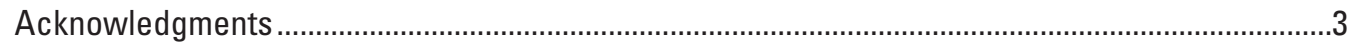

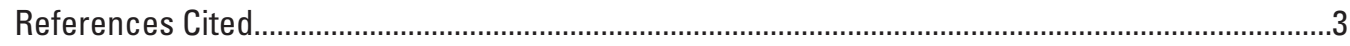

\section{Table}

1. Compilation of geologic, lead isotope, mineral deposit type, and sample mineralogic data for samples from the Russian Far East ........................................... link 


\section{Conversion Factors}

SI to Inch/Pound

\begin{tabular}{lcl}
\hline \multicolumn{1}{c}{ Multiply } & By & \multicolumn{1}{c}{ To obtain } \\
\hline microliter $(\mu \mathrm{L})$ & Length & \\
milliliter $(\mathrm{mL})$ & 0.000034 & centimeter $(\mathrm{cm})$ \\
liter $(\mathrm{L})$ & 0.3382 & millimeter $(\mathrm{mm})$ \\
liter $(\mathrm{L})$ & 33.82 & meter $(\mathrm{m})$ \\
\hline & 0.2642 & kilometer $(\mathrm{km})$ \\
\hline milligram $(\mathrm{mg})$ & Mass & \\
gram $(\mathrm{g})$ & 0.000035 & ounce, avoirdupois $(\mathrm{oz})$ \\
\hline
\end{tabular}

1 nanogram $(\mathrm{ng})$ equals $1.0 \times 10^{-9} \mathrm{gram}$.

Temperature in degrees Celsius $\left({ }^{\circ} \mathrm{C}\right)$ may be converted to degrees Fahrenheit $\left({ }^{\circ} \mathrm{F}\right)$ as follows:

$$
{ }^{\circ} \mathrm{F}=\left(1.8 x^{\circ} \mathrm{C}\right)+32
$$

Temperature in degrees Fahrenheit $\left({ }^{\circ} \mathrm{F}\right)$ may be converted to degrees Celsius $\left({ }^{\circ} \mathrm{C}\right)$ as follows:

${ }^{\circ} \mathrm{C}=\left({ }^{\circ} \mathrm{F}-32\right) / 1.8$ 


\title{
Lead Isotope Determinations from Sulfide Mineral Occurrences-Russian Far East
}

\author{
By Stanley E. Church, ${ }^{1}$ Nikolai A. Goryachev, ${ }^{2}$ and Vladimir I. Shpikerman ${ }^{3}$
}

\section{Introduction}

The lead isotope database for sulfide deposits and occurrences in the Russian Far East was funded by the Mineral Resources Program, U.S. Geological Survey (USGS) in conjunction with the collaborative studies of mineral resources by the Russian Academy of Sciences and the U. S. Geological Survey (Nokleberg and others, 1996). Comparisons of these data with similar lead isotope data from Alaska published in Church, Delevaux, and others (1987) and Gaccetta and Church (1989) provide a basis for the following three-fold project objectives:

1. To utilize lead isotope signatures, in conjunction with regional mapping, to assess the relative ages and to categorize the types of mineral deposits studied,

2. To relate the lead isotope and trace-element geochemical signatures of specific deposits and occurrences to oreforming processes, and

3. To use the lead isotope data to correlate lithotectonic terranes within the northern Cordillera (Alaska, Yukon Territories and British Columbia in Canada, and the western Cordillera of the United States).

The report by Church, Gray, and others (1987) shows how this fingerprinting methodology can be applied to trace the offset of lithotectonic (or lithostratigraphic as labeled by some authors) terranes. The lead isotope data presented in table 1 represent the work completed on sulfide mineral deposits located in the Russian Far East from 1993 to 1995 , when this study was terminated due to lack of funding. The lead isotope data are reported here for use by investigators who may find them of value in mineral exploration. No attempt is made to summarize the voluminous literature on these mineral deposits.

\footnotetext{
${ }^{1}$ U.S. Geological Survey
}

${ }^{2}$ Russian Academy of Sciences, Magadan, Russian Federation

${ }^{3}$ Ministry of Natural Resources and Ecology of the Russian Federation, St. Petersburg, Russian Federation

\section{Deposit Information}

Geologic and site information on each specific deposit or occurrence has been provided largely by the sample contributors on the field form used for sample submission. All sites have been evaluated by comparing the data provided against the data in the USGS Mineral Resource Data System (MRDS; accessed June 29, 2010 at http://tin.er.usgs. gov/mrds/). Specific geologic information about the deposit or occurrence was also obtained from published literature referenced therein. Contributors were given the opportunity to modify the descriptive data in the tables. This process should have minimized errors. The deposit classification used in this report is from the compilation by Cox and Singer (1986) and is included here only for the purpose of dialogue. There is no widespread agreement among geologists on the classification of deposits into model types.

\section{Samples and Analytical Techniques}

We report analyses from several types of sulfide samples: first, analyses made on those that contain galena (lead sulfide, indicated by GN in the sample mineralogy column) or tetrahedrite (TT) that could be hand separated, and analyses on either mixed sulfides. In addition, lead isotope determinations have been made largely on samples containing mixed sulfide. Where mixed sulfides were analyzed, we report the lead concentration determined in the sample either by direct-currentarc emission spectrography on the powdered sulfide material or that determined in the solution used for lead isotope analysis by atomic absorption spectrophotometry. Previous studies of mixed sulfides, or of separate sulfide minerals that had 100 part per million (ppm) or more of lead, indicate that the lead isotope data obtained from this type of sample were comparable to those obtained from galena (for example, Church and others, 1986; Gulson, 1986).

Several different chemical procedures were used on samples analyzed in this study. Galena has been handpicked for analysis where possible. Galena samples were prepared for analysis by digestion with ultrapure warm 16 Molar (M) $\mathrm{HNO}_{3}$ (2-5 milligrams $(\mathrm{mg})$ of galena in $1 \mathrm{~mL}$ ). The samples 
were then diluted to $10 \mathrm{~mL}$ with deionized water, analyzed by atomic absorption spectrometry to determined the approximate lead concentration ( \pm 10 percent), and sufficient solution pipetted out so that 1 microgram $(\mu \mathrm{g})$ of lead was available for isotope analysis (usually about $1-10$ microliter $(\mu \mathrm{L})$ ).

Mixed sulfides were digested in hot ultrapure $12 \mathrm{M}$ $\mathrm{HCl}, 16 \mathrm{M} \mathrm{HNO}_{3}$, or aqua regia, depending upon the sulfide minerals present. The solution was decanted, evaporated to dryness, and converted first to the chloride medium and then to the bromide medium. Lead was isolated from other cations using anion exchange resin (AG-1, Bio-Rad Laboratories, Inc., https://www.bio-rad.com/) in the bromide medium. Analytical blanks were less than 2.5 nanogram (ng) and have a negligible impact on the reported lead isotope ratios. The sample was loaded on the anion exchange resin (AG-1) in $0.75 \mathrm{M}-1.0 \mathrm{M}$ $\mathrm{HBr}$, washed with $1.0 \mathrm{M} \mathrm{HBr}$, and then with $1.5 \mathrm{M} \mathrm{HC}$. The lead was then eluted with $6 \mathrm{M} \mathrm{HC1}$.

Molybdenite samples were digested in hot ultrapure $6 \mathrm{M} \mathrm{HCl}$. A white precipitate, probably $\mathrm{Mo}_{3} \mathrm{Cl}_{4}(\mathrm{OH})_{2} \cdot 2 \mathrm{H}_{2} \mathrm{O}$, formed and the lead remained in solution. The solution was decanted, evaporated to dryness, and converted to the $\mathrm{HBr}$ medium. Lead was purified by anion exchange (AG-1) in the bromide medium.

Samples containing high concentrations of Sb-bearing sulfides required special preparation because antimony is also adsorbed onto the anion exchange resin (AG-1) in the bromide medium. These samples (tetrahedrite-bearing samples) were digested in ultrapure $12 \mathrm{M} \mathrm{HC1}$ in quartz beakers. The sample was then evaporated to dryness, driving off much of the volatile $\mathrm{SbCl}_{3}$ and leaving lead in the residue. The sample residue was dissolved in $\mathrm{HBr}$ and final separation of the lead was done by anion exchange (AG-1) in the bromide medium.

Following the primary separation of lead from other cations using the $\mathrm{HBr}$ column procedure, lead samples were further cleaned in a small $\mathrm{HCl}$ anion exchange column prior to analysis. Rarely was it necessary to electroplate the lead samples obtained prior to mass spectrometric analysis, however, when necessary, electro-deposition on a platinum anode was also used; blanks from the electroplating step were $<1$ ng and were neglible.

All of the lead isotope data presented in table 1 have been analyzed using the silica-gel emitter method (Cameron and others, 1969). Approximately $0.5 \mu \mathrm{g}$ of lead was taken up in approximately $10 \mu \mathrm{L}$ of dilute colloidal silica gel, loaded onto a rhenium-ribbon filament, and evaporated to dryness. The filament is then loaded into a solid-source thermal ionization mass spectrometer and heated to $1,150-1,350^{\circ} \mathrm{C}$ for data acquisition. Analyses by Ken Ludwig (listed as KL in the Analyst column of table 1) were made using a VG Instruments Sector 54, 7-collector mass spectrometer run in "static" mode. Analyses by Robert Vaughn (listed as RV) were run on a single collector, NBStype 12-inch solid source mass spectrometer described in Gaccetta and Church (1989). Analyses of National Institute for Standards and Technology Standard Reference Material 981 (NIST SRM 981, Common Lead Isotopic Standard) were used to monitor mass fractionation during mass spectrometry (Cantanzaro and others, 1968; Todt and others, 1996). The lead isotope data have all been corrected for thermal fractionation using the National Bureau of Standards (NBS) SRM-981 common-Pb standard (Catanzaro and others, 1968 ) and are corrected for mass discrimination of $0.11 \pm$ 0.04 percent per amu. Results are generally accurate, at the 2 sigma level, to within \pm 0.1 percent/mass unit or better; analytical errors are reported in table 1.

\section{Results}

The analytical data are summarized in table 1. Geologic data are summarized from Nokleberg and others (1996). Site descriptions for most of the samples analyzed are listed therein by Site Number. Standard abbreviations are used for geologic time periods for the age of the host rock and the time of mineralization. Minerals are listed in decreasing order of abundance based on visual analysis of hand specimens.

Mineral abbreviations used in the column marked Mineralogy are:

ang, anglesite; ank, ankerite; asp, arsenopyrite; Au, gold; $\mathrm{Ag}$, silver or mixed silver-bearing minerals; bg, boulangerite; bar, barite; bn, bornite; Bi, bismuth-bearing minerals; cal, calcite; cc, chalcocite; ch, chrysocolla; cn, cinnabar; cp, chalcopyrite; cr, chromite; cs, cerussite; cu, cuprite; cv, covelite; dl, dolomite; ep, epidote; fl, fluorite; gn, galena (GN where a handpicked separate is used for chemical analysis); gt, garnet; hm, hematite; lm, limonite; ma, malachite; mar, marcasite; mly, molybdenite; mt, magnetite; po, pyrrohotite; px, pyroxene; py, pyrite; qz, quartz; REE, rare-earth minerals; rut, rutile; $\mathrm{Sb}$, antimony-bearing minerals; sch, scheelite; si, siderite; sl, sphalerite; Sn, tin-bearing minerals; ss, smithsonite; st, stibnite; stn, stannite; sulfosalts, mixed sulfosalt minerals, tt, tetrahedrite (TT where a handpicked separate is used for chemical analysis); and tu, tourmaline.

Age abbreviations used in the columns marked Geologic Host Age and Mineralization Age are:

$\begin{array}{ll}\text { Era } & \text { Period } \\ \text { Mz Mesozoic } & \text { K Cretaceous } \\ & \text { J Jurassic } \\ \text { Rz Paleozoic } & \text { P Triassic } \\ & \text { P Permian } \\ & \text { M Mississippian } \\ & \text { D Devonian } \\ & \text { S Silurian } \\ & \text { O Ordovician } \\ & \text { C Cambrian }\end{array}$

p€ Precambrian, probably Neoproterozoic(?)

Subdivisions of periods are designated as early (e), middle ( $\mathrm{m}$ ), and late (1). 


\section{Acknowledgments}

The two Russian co-authors, Nikolai A. Goryachev and Vladimir I. Shpikerman, did not visit all of the deposits or occurrences from which we have reported analytical data. Many geologists have contributed samples for this compilation. To them, we express our thanks for providing samples and field information for each of these mineral occurrences.

\section{References Cited}

Cameron, A.E., Smith, D.H., and Walker, R.L., 1969, Mass spectrometric analysis of nanogram quantities of lead: Analytical Chemistry, v. 41, p. 525-526.

Catanzaro, E.J., Murphy, T.J., Shields, W.R., and Garner, E.L., 1968, Absolute isotopic abundance ratios of common, equal-atom, and radiogenic lead isotopic standards: Journal of Research, National Bureau of Standards, v. 72A, p. 261-267.

Church, S.E., Delevaux, M.H., and Gray, J.E., 1987, $\mathrm{Pb}$-isotope data base for sulfides from Alaska, March, 1987: U.S. Geological Survey Open-File Report 87-259, 44 p.

Church, S.E., Gray, J.E., Delevaux, M.H., and LeHuray, A.P., 1987, Lead-isotope signatures of Devonian-Mississippian massive sulfide deposits in Alaska and their significance to mineral exploration, in Elliott, I.L. and Smee, B.W., eds., GEOEXPO/86 Exploration in the North American Cordillera: Ontario, Assoc. Exploration Geochemists, p. 132-141.

Church, S.E., LeHuray, A.P., Grant, A.R., Delevaux, M.H. and Gray, J.E., 1986, Lead-isotopic data from sulfide minerals from the Cascade Range, Oregon and Washington: Geochimica et Cosmochimica Acta, v. 50, p. 317-328.
Cox, D.P., and Singer, D.A., eds., 1986, Mineral deposits models: U.S. Geological Survey Bulletin 1693, 379 p. Available at http://pubs.usgs.gov/bul/b1693/.

Gaccetta, J.D., and Church, S.E., 1989, Lead isotope data base for sulfides from Alaska, December, 1989: U.S. Geological Survey Open-File Report 89-688, 60 p, http://pubs.er.usgs.gov/publication/ofr 89688.

Gulson, B.L., 1986, Lead isotopes in mineral explorationDevelopments in economic geology: Elsevier, New York, $245 \mathrm{p}$.

Nokleberg, W.J., Bundtzen, T.K., Dawson, K.M., Eremin, R.A., Goryachev, N.I., Koch, R.D., Ratkin, V.V., Rozenblum, I.S., Shpikerman, V.I., Frolov, Y.F., Gorodinsky, M.E., Melnikov, V.D., Ognyanov, N.V., Petrachenko, E.D., Petrachenko, R.I., Pozdeey, A.I., Ross, K.V., Wood, D.H., Grybeck, Donald, Khanchuck, A.I., Kovbas, L.I., Nekrasov, I.Y., and Siderov, A.A., 1996, Significant metalliferous and selected non-metalliferous lode deposits and placer districts for the Russian Far East, Alaska, and the Canadian Cordillera: U.S. Geological Survey Open-File Report 96-513A, 325 p., http://pubs.er.usgs.gov/publication/ofr96513A.

Nokleberg, W.J., Bundtzen, T.K., Eremin, R.A., Ratkin, V.V., Dawson, K.M., Shpikerman, V.I., Goryachecv, N.A., Byalobzhesky, S.G., Frolov, Y.F., Khanchuk, A.I., Koch, R.D., Monger, J.W.H., Pozdeev, A.I., Rozenblum, I.S., Rodionov, S.M., Parfenov, L.M., Scotese, C.R., and Siderov, A.A., 2005, Metallogenesis and tectonics of the Russian Far East, Alaska, and the Canadian Cordillera: U.S. Geological Survey Professional Paper 1697.

Todt, W., Cliff, R. A., Hanser, A. and Hofmann, A. W., 1996, Evaluation of a $202 \mathrm{~Pb}-205 \mathrm{~Pb}$ double spike for highprecision lead isotopic analysis, in Basu, A. and Hart, S. R., eds., Earth Processes - Reading the Isotopic Code: American Geophysical Union, Geophysical Monograph 95, p. 429-437. 
Publishing support provided by:

Denver Publishing Service Center

For more information concerning this publication, contact:

Center Director, USGS Central Mineral and Environmental Resources

Science Center

Box 25046, Mail Stop 973

Denver, CO 80225

(303) 236-1562

Or visit the Central Mineral and Environmental Resources Science

Center Web site at:

http://minerals.cr.usgs.gov/ 
